\title{
Dihydroxyacetone as a definitive treatment for aluminium phosphide poisoning in rats
}

\author{
Jafar Ahmadi ${ }^{1,2}$, Siyavash Joukar ${ }^{3,4}$, Hussein Anani ${ }^{5}$, and Somayyeh Karami-Mohajeri ${ }^{1,2}$ \\ Pharmaceutics Research Center, Institute of Neuropharmacology ${ }^{l}$, Department of Toxicology and Pharmacology ${ }^{2}$, \\ Physiology Research Center, Institute of Basic and Clinical Physiology Sciences ${ }^{3}$, Department of Physiology and \\ Pharmacology ${ }^{4}$, Faculty of Allied Medical Sciences ${ }^{5}$, Kerman University of Medical Sciences, Kerman, Iran
}

[Received in February 2018; Similarity Check in February 2018; Accepted in May 2018]

\begin{abstract}
Aluminium phosphide (AlP), a very toxic pesticide also known as the rice tablet, releases phosphine gas upon contact with water, moisture, or gastric acid. Its mortality rate in humans is $70-100 \%$ due to cardiogenic shock and refractory hypotension. Dihydroxyacetone (DHA) is a simple ketonic carbohydrate, mainly used for sunless skin tanning. It also plays a beneficial role in the treatment of hypotension and cardiogenic shock by restoring blood volume and cellular respiration. The aim of this study was to investigate the its effect on the haemodynamics and electrocardiogram (ECG) in male rats poisoned with AlP. The animals were divided into the following groups: control (received $1 \mathrm{~mL}$ corn oil, orally), AlP (received $15 \mathrm{mg} \mathrm{kg}^{-1}$ AlP solved in corn oil, orally), AlP plus DHA (treated with $50 \mathrm{mg} \mathrm{kg}^{-1}$ of DHA 30 min after receiving AIP), and AIP plus $N$-acetyl cysteine (NAC) (treated with $200 \mathrm{mg} \mathrm{kg}^{-1}$ of NAC 30 min after receiving AIP). The animals were then anaesthetised and ECG, blood pressure, and heart rate were recorded for 120 min. Treatment with AlP alone and in combination with NAC was associated with progressive hypotension, tachycardia, and ECG disturbances in rats, resulting in $100 \%$ mortality $3 \mathrm{~h}$ after poisoning. However, DHA achieved $100 \%$ survival in the poisoned rats and prevented AlP-induced ECG and haemodynamic abnormalities. The main mechanism of DHA in the treatment of AlP poisoning is unclear, but the findings suggest the promising therapeutic potential of DHA against AIP poisoning.
\end{abstract}

KEY WORDS: acute toxicity; AlP; DHA; N-acetyl cysteine; NAC; pesticides; refractory hypotension; rice tablet

While the application of pesticides in agriculture has improved the quality and quantity of agricultural products around the world (1), its death toll as a result of deliberate, accidental, occupational, or criminal poisoning has become an important issue (2).

Aluminium phosphide (AlP), also known as the rice tablet, is a highly effective and accessible solid fumigant widely used to protect agricultural products from pests (3). It is the most common cause of death among the residents of developing countries such as Iran and India, with the rate of $70-100 \%$. Death often occurs during the first 12 to $24 \mathrm{~h}$ of poisoning $(4,5)$.

On contact with moisture, water, or gastric acid, AlP releases a lethal gas called phosphine (6). Its absorption begins immediately after ingestion, and the symptoms are nonspecific, including nausea, vomiting, abdominal pain, pulmonary oedema, cardiovascular changes, seizure, hypoglycaemia, and lactic acidosis $(1,7,8)$. The exact mechanism of phosphine gas poisoning has not yet been determined, but previous studies suggest inhibition of cellular respiration through the inhibition of cytochrome $\mathrm{C}$ oxidase, induction of oxidative stress via over-production of free radicals, and reduction of antioxidant enzymes (4).

Correspondence to: Somayyeh Karami-Mohajeri, Faculty of Pharmacy, Haft Bagh-e-Alavi Highway, Kerman, 7616911319, Iran Email: s_mohajeri@kmu.ac.ir or somayyehkarami@gmail.com
Although phosphine is a non-specific poison affecting most organs, it particularly affects the cardiovascular system with electrocardiogram (ECG) disturbances, myocardial damage, collapse of vessels, congestive heart failure, arrhythmia, cardiogenic shock, and refractory hypotension $(3,9)$.

The management of AlP poisoning has mostly been supportive and, unfortunately, no specific antidote has been discovered so far. The strategies that have been proposed include preventing the hydrolysis of AlP and reducing the absorption of phosphine with gastric lavage with potassium permanganate, paraffin, and coconut oil. Management also includes the use of vasopressors, anti-arrhythmic drugs, digoxin, temporary cardiac pacing, and antioxidants such as $N$-acetyl cysteine (NAC) and vitamins E and C (1). Mechanical methods such as extracorporeal membrane oxygenation and balloon pump in the aorta have been shown to increase the survival time (10-12). Several in vitro studies reported that intravenous hydroxyethyl starch (13) prevented the leaking of intravascular fluids, that milrinone and vasopressin managed hypotension (14), and that $\mathrm{N}(\omega)$ nitro-L-arginine methyl ester (L-NAME) inhibited nitric oxide synthesis (15). However, no research so far has come up with a successful method or pharmacological compound for the definitive treatment of AlP poisoning.

Yet, some hope looms from most unexpected places with a cosmetic tanning product dihydroxyacetone (DHA) 
(16-20). This simple ketonic carbohydrate has been shown to effectively treat haemorrhagic and hypovolemic shock induced by lactic acidosis (21) and to restore mitochondrial respiration by suppressing cytochrome $\mathrm{C}$ oxidase inhibition by cyanide in mice and rabbits $(22,23)$. It also countered phosphine gas toxicity in the HepG2 cell line by increasing the production of ATP through glycolysis (24) and proved helpful in the treatment of acute anoxia in cases of cardiovascular collapse, myocardial infarction, general metabolic acidosis, and fatigue-induced lactic acidosis by restoring the phagocytic activity (21).

All these findings have prompted us to investigate the efficiency of DHA in the treatment of cardiac shock, blood pressure, and ECG in male rats poisoned with AlP.

\section{MATERIALS AND METHODS}

\section{Chemicals}

AlP in the form of granules packed in moisture-resistant sachets was purchased from the pesticide manufacturing company Samiran (Tehran, Iran). DHA was obtained from Merck Co. (Darmstadt, Germany). Other chemicals, all of high purity, were purchased from Sigma Aldrich (St. Louis, MO, USA).

\section{Determination of $L D_{100}$ of AlP}

Based on earlier reports of the AlP $\mathrm{LD}_{50}$ and $\mathrm{LD}_{100}$ in rats of $8.7-12 \mathrm{mg} \mathrm{kg}^{-1}$ (25) and $20 \mathrm{mg} \mathrm{kg}^{-1}$, respectively (26), we reran the tests with the range of $8-20 \mathrm{mg} \mathrm{kg}^{-1}$ of AlP dissolved in corn oil and administered it orally (to six rats in each group) to mimic real-life mortality with a single dose. Mortality rates were calculated after $24 \mathrm{~h}$ of AlP administration using the probit analysis.

\section{Animals}

All animal experiments were performed in accordance with relevant ethical guidelines for animal use, which was approved by the Ethics Committee of the Kerman University of Medical Sciences (Ethics code: IR.KMU. REC.1396.1964). Male Wistar rats weighing 250 $\pm 20 \mathrm{~g}$ were purchased from the animal house of the Kerman University of Medical Sciences. Before the experiments started, the animals were kept in the laboratory for 7 days in order to adapt to the environment. During the study, the animals were kept in a controlled environment with a temperature of 22-24 ${ }^{\circ} \mathrm{C}$ and a 12-hour darkness / light cycle, with free access to food and water.

\section{Study design}

Thirty rats were randomly divided into four groups (six rats in each group), as follows. Group 1 consisted of healthy control rats which received a single oral dose of $1 \mathrm{~mL}$ of corn oil alone through gavage (control group). Group 2 included healthy rats poisoned with a single oral dose of $15 \mathrm{mg} \mathrm{kg}^{-1}$ of AlP in $1 \mathrm{~mL}$ of corn oil (AlP group). Group 3 consisted of AlP-poisoned rats treated with a single oral dose of $50 \mathrm{mg} \mathrm{kg}^{-1}$ of DHA in $1 \mathrm{~mL}$ of $5 \%$ dextrose $30 \mathrm{~min}$ after AlP administration (AlP+DHA). Group 4 consisted of AlP-poisoned rats treated with a single intraperitoneal dose of $200 \mathrm{mg} \mathrm{kg}^{-1}$ of NAC in $1 \mathrm{~mL}$ of $5 \%$ dextrose $30 \mathrm{~min}$ after AlP administration (AlP+NAC).

The animals were anaesthetised with ketamine/xylazine (60/6 $\left.\mathrm{mg} \mathrm{kg}^{-1}\right) 30 \mathrm{~min}$ after administration of AlP (27). To maintain anaesthesia, ketamine/xylazine dosing $\left(30 / 3 \mathrm{mg} \mathrm{kg}^{-1}\right)$ was repeated 60 and $90 \mathrm{~min}$ after AlP poisoning.

\section{Monitoring of survival time}

Survival was monitored continuously by direct observation of rats in all groups for the first $6 \mathrm{~h}$. After that, the groups were checked for survival every $6 \mathrm{~h}$ for more than $24 \mathrm{~h}$.

\section{Recording of ECG, systolic blood pressure, heart rate, shock index, and survival}

The anaesthetised animals were immediately monitored for ECG, systolic blood pressure (SPB), and heart rate (HR) and the readings forwarded to a PowerLab data acquisition instrument (ML870, AD Instruments, Bella Vista, Australia). More specifically, the electrodes for recording lead II ECG were subcutaneously connected to the limbs of animals $(14,25)$, and ECG and HR monitored and recorded for $2 \mathrm{~h}$. The ECG data were then analysed using LabChart Pro Modules (AD Instruments). Baseline RR interval (i.e. the time between two successive $\mathrm{R}$ waves) and QT interval (i.e. the time from the beginning of the Q wave to the end of the T wave) were calculated based on 2-minute ECG-recorded strips. To obviate the dependence of the QT interval on HR, corrected QT (QTc) intervals were calculated using Bazett's formula, normalised as QTcn$\mathrm{B}=\mathrm{QT} /(\mathrm{RR} / \mathrm{f})^{1 / 2}$, where and $\mathrm{f}=150 \mathrm{~ms}(28)$.

SBP was also measured using a non-invasive method through a cuff attached to the rat tail. Shock index (SI) was calculated by dividing HR by SBP (29). Several studies have shown that SI is a better indicator of haemorrhagic shock than blood pressure or HR alone $(30,31)$. A rise in SI precedes hypotension and is an early sign of haemodynamic instability due to cardiovascular diseases such as cardiac ischaemia, myocardial infarction, and heart failure $(32,33)$.

\section{Statistical analysis}

All analyses were performed using the GraphPad-Prism 5.0 software (San Diego, CA, USA). Survival curves were plotted using the Kaplan-Meier method and its statistical significances were determined using the post hoc log-rank test. All data were normally distributed, as confirmed by the Shapiro-Wilk's test. Two-way repeated measure 
ANOVA test followed by Tukey's post-hoc test was used for data analysis. P values of less than 0.05 were considered statistically significant.

\section{RESULTS}

\section{Probability of survival and survival time}

No mortality was reported in the control and AlPpoisoned animals treated with DHA. However, the untreated poisoned animals and those that received NAC after poisoning died after an average of $148.1 \pm 32.2 \mathrm{~min}$ and $136.2 \pm 21 \mathrm{~min}$, respectively. Figure 1 shows the probability $(\%)$ of survival in all four groups.

\section{$H R, S B P$, and $E C G$}

Table 1 shows the SPB and HR findings in the four groups. Animals poisoned with AlP (group 2) exhibited a time-dependent systolic hypotension that became significant in respect to control $60 \mathrm{~min}$ after the poisoning. Tachycardia became significant $90 \mathrm{~min}$ after the poisoning.

The AlP+DHA animals (group 3) showed no significant change in SBP or in HR in respect to control.

In the $\mathrm{AlP}+\mathrm{NAC}$ rats, $\mathrm{SBP}$ decreased and $\mathrm{HR}$ increased with time.

The shock index (Figure 2) reinforces the SPB and HR findings of time-dependent and significant increase in in the $\mathrm{AlP}$ and $\mathrm{AlP}+\mathrm{NAC}$ groups. In the $\mathrm{AlP}+\mathrm{DHA}$ group it was similar to control.

ECG abnormalities such as shorter RR, ST elevation (Table 2), and prolonged QTc (Figure 3) were also observed in the AlP-poisoned rats. In contrast, DHA significantly eliminated ECG abnormalities. The lethal dose of AlP caused a non-significant drop in the QRS interval, but it dropped significantly in the AlP+NAC group (Table 2).

\section{DISCUSSION}

The results of our study are pretty straightforward and conclusive: DHA completely eliminated tachycardia in AlP-poisoned rats, probably because it prevented severe hypotension. It is well known that HR is affected by changes in oxygen levels in the body to compensate for its lack through greater cardiac output (34). However, high HR can result in cardiac ischaemia, ventricular arrhythmias, and left ventricular dysfunction (35), which eventually led to death in groups 2 and 4.

SI showed a significant increase in the AlP-poisoned rats (group 2) early compared to controls and it grew with time, which can be associated with left ventricular dysfunction and myocardial damage. SI can also be a good indicator of the quality of treatment and cardiovascular status in the early stage of poisoning with AlP.

ECG parameters reinforced the findings of tachycardia, hypotension, and SI in the poisoned rats. The ST elevation was first recorded $60 \mathrm{~min}$ after AlP poisoning and continued to rise with time until the rats died. This is in line with earlier reports that AIP poisoning leads to ST elevation (36, 37). In acute poisoning with AlP, ST elevation correlates closely with mortality, and its lowering can indicate successful treatment $(3,36)$. The case in point is the ST segment in DHA-treated AlP-poisoned rats, which was consistent with the one in the control group. DHA

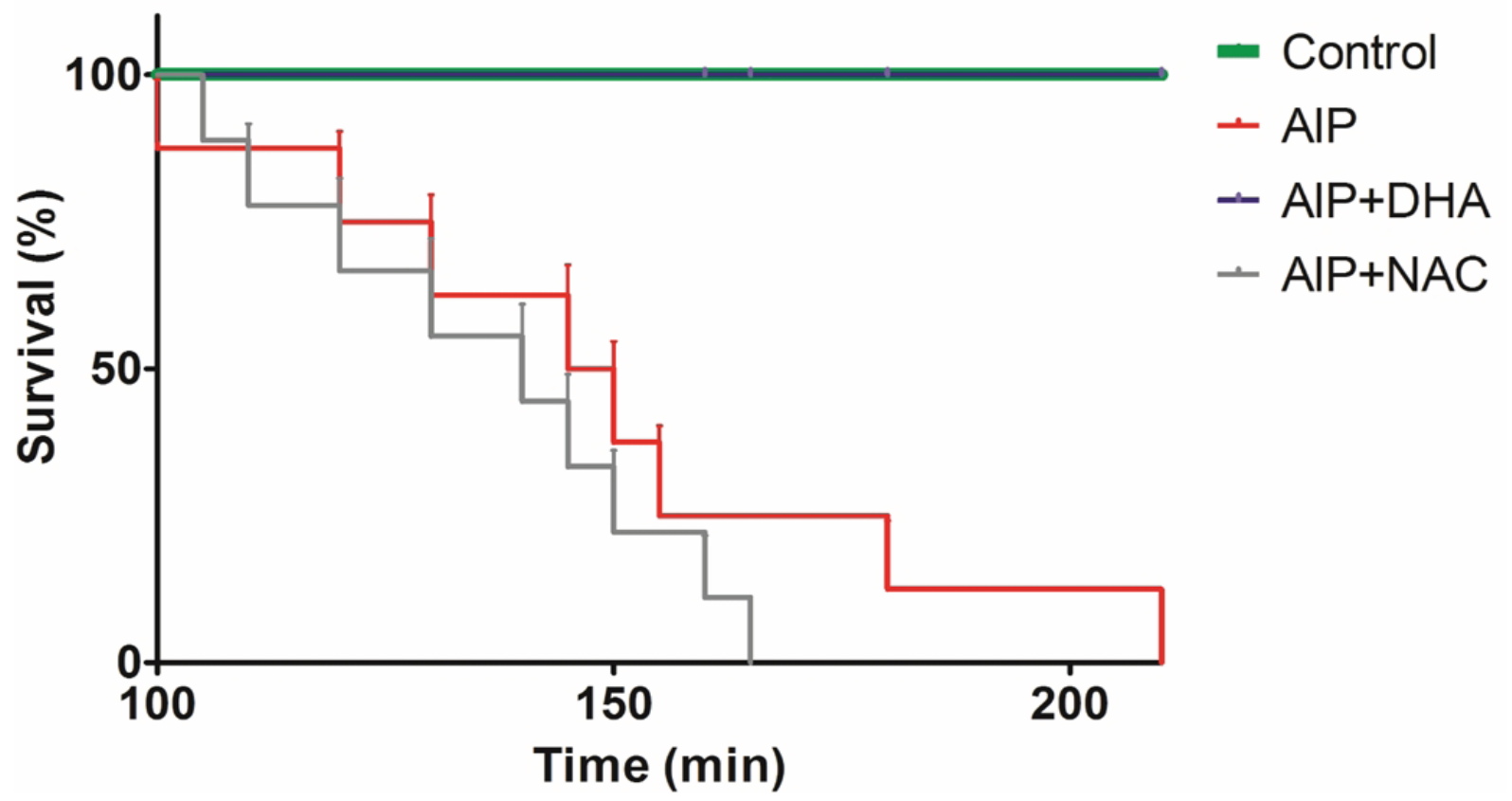

Figure 1 Overall survival across study groups (in percentages). Control - rats receiving only corn oil; AlP - rats poisoned with a single aluminium phosphide dose (15 $\left.\mathrm{mg} \mathrm{kg}^{-1}\right) ; A l P+D H A-A l P$-poisoned rats treated with a single DHA dose $\left(50 \mathrm{mg} \mathrm{kg}^{-1}\right) ; A l P+N A C-A l P$ poisoned rats treated with a single NAC dose $\left(200 \mathrm{mg} \mathrm{kg}^{-1}\right)$ 


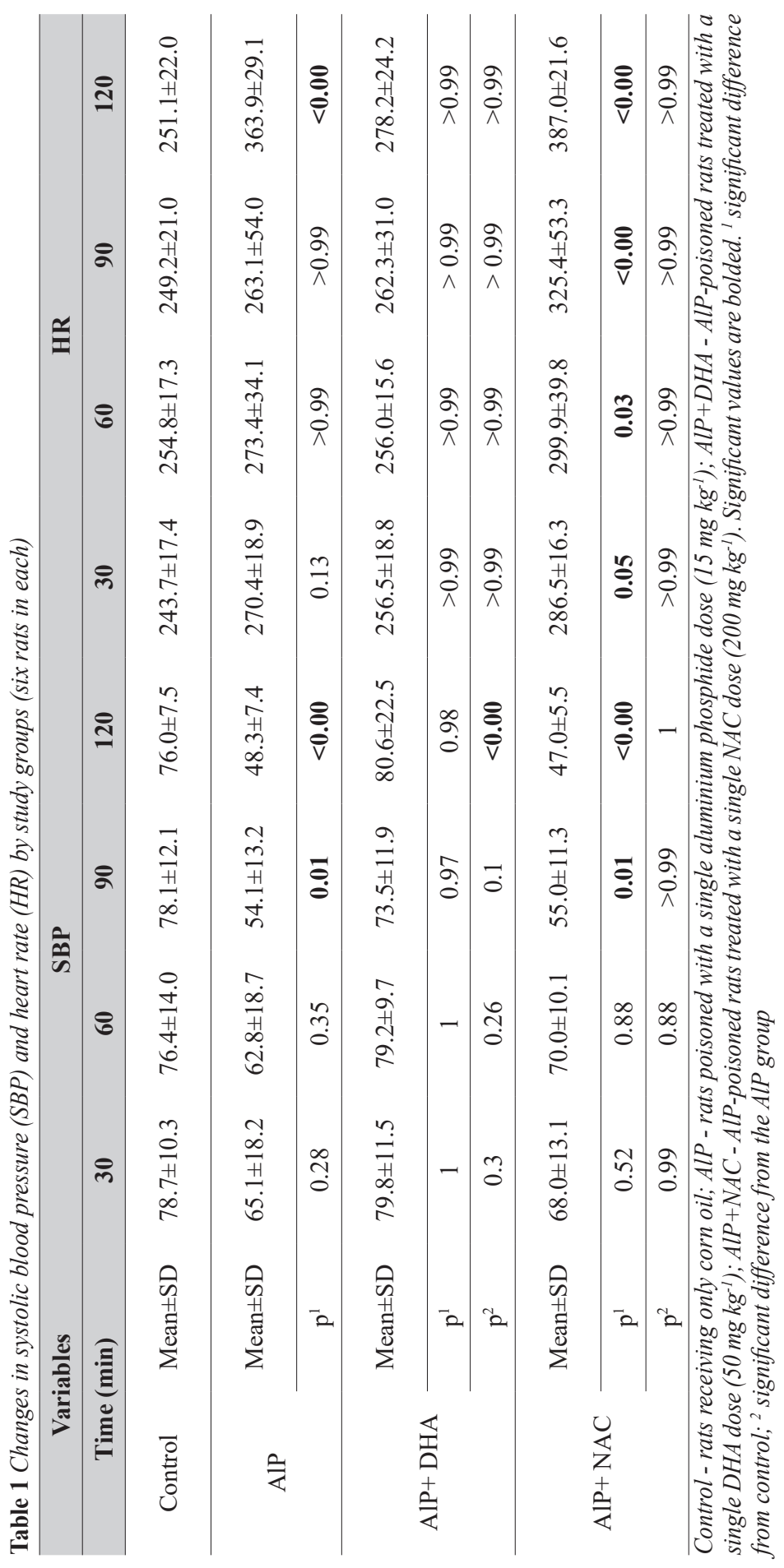




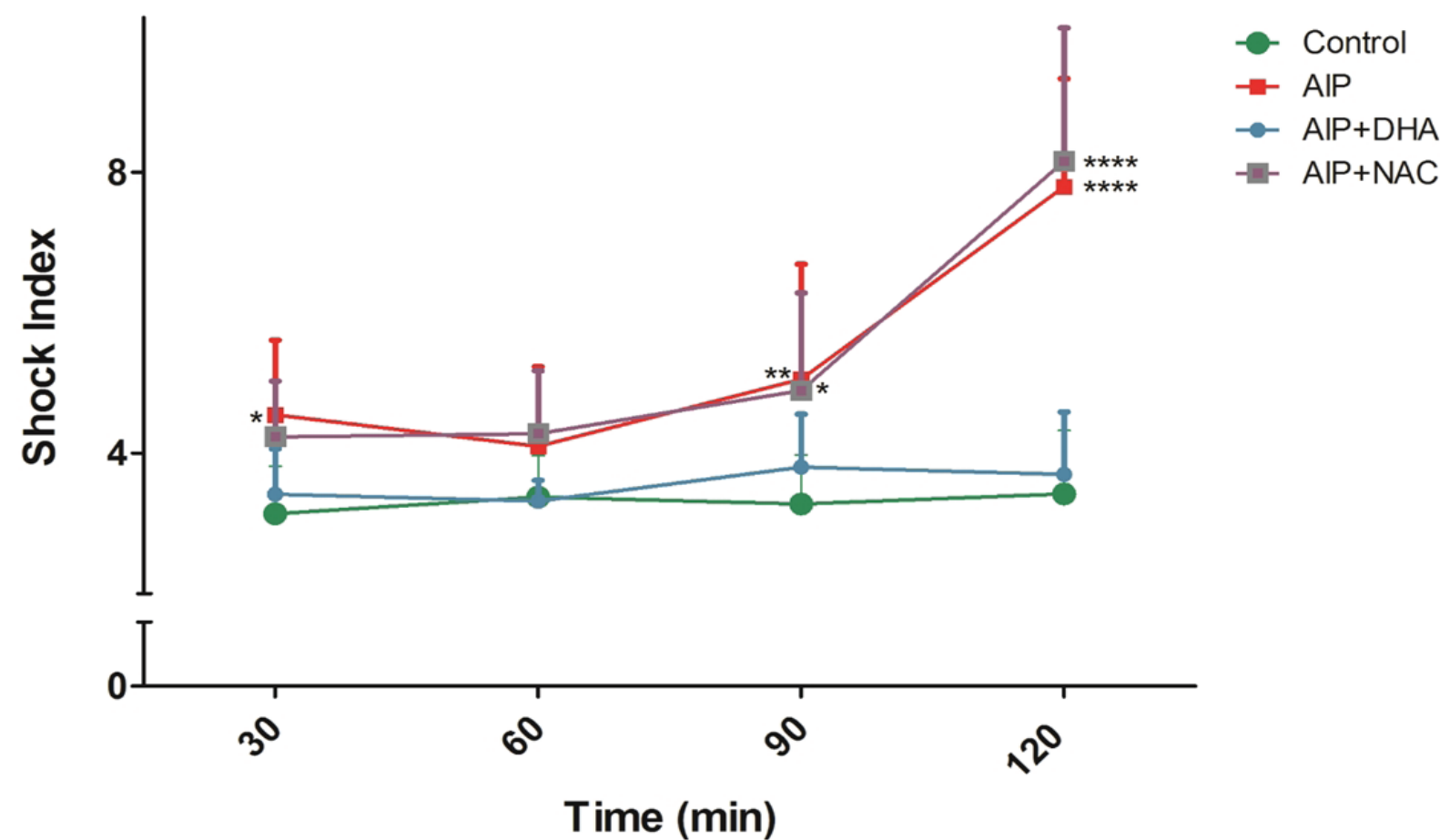

Figure 2 Changes in shock index (SI) across study groups (6 rats in each). Control - rats receiving only corn oil; AlP - rats poisoned with a single aluminium phosphide dose $\left(15 \mathrm{mg} \mathrm{kg}^{-1}\right)$; AlP $+D H A$ - AlP-poisoned rats treated with a single DHA dose $\left(50 \mathrm{mg} \mathrm{kg}^{-1}\right)$;

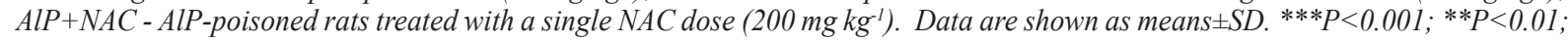
$* P<0.05$

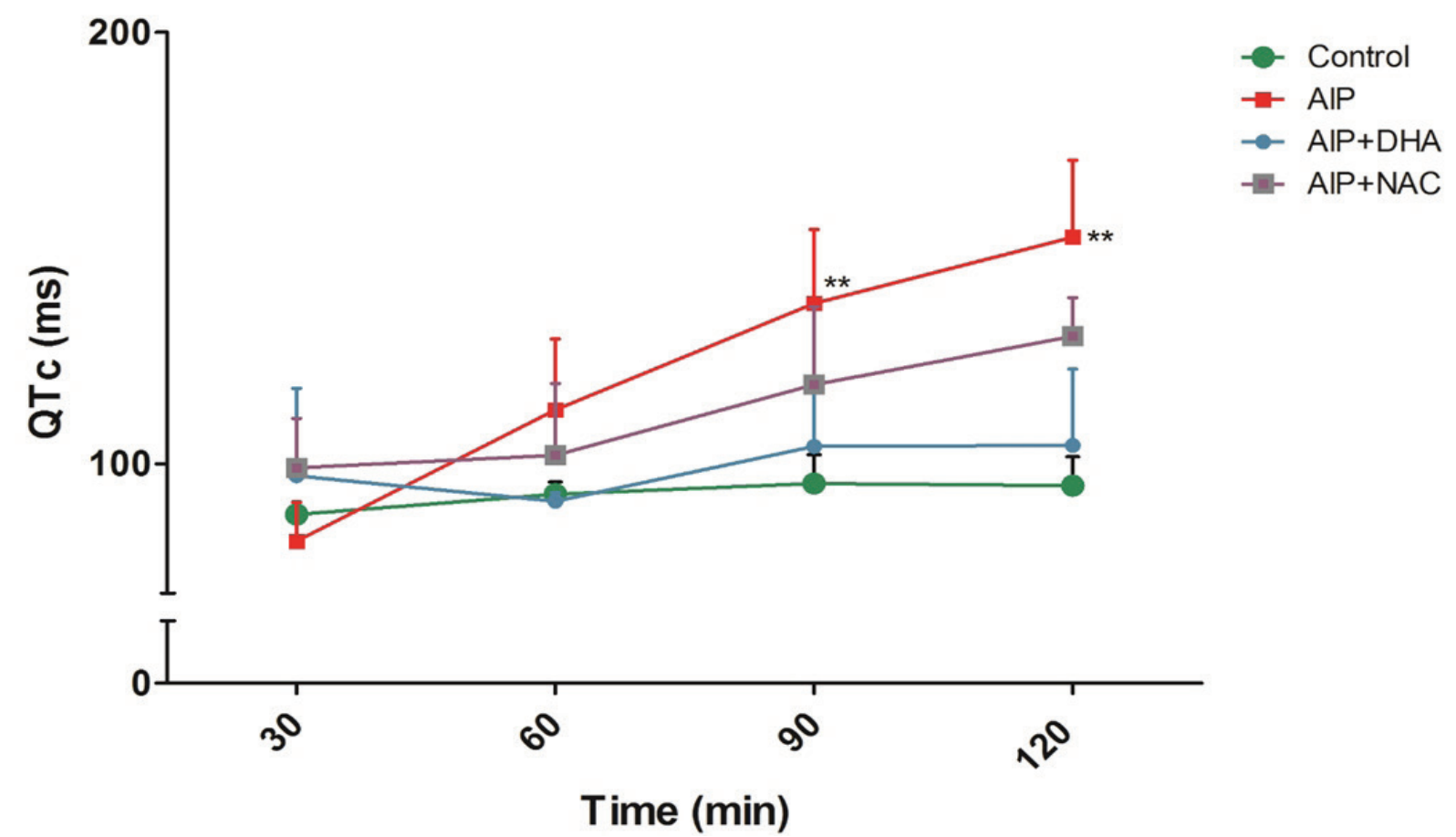

Figure 3 Changes in QTc across study groups (6 rats in each). Control - rats receiving only corn oil; AlP - rats poisoned with a single aluminium phosphide dose $\left(15 \mathrm{mg} \mathrm{kg}^{-1}\right) ; A l P+D H A-A l P$-poisoned rats treated with a single DHA dose $\left(50 \mathrm{mg} \mathrm{kg}^{-1}\right) ; A l P+N A C-A l P$ poisoned rats treated with a single NAC dose $\left(200 \mathrm{mg} \mathrm{kg}^{-1}\right)$. Data are shown as means $\pm S D$. ${ }^{* * P}<0.01$ 


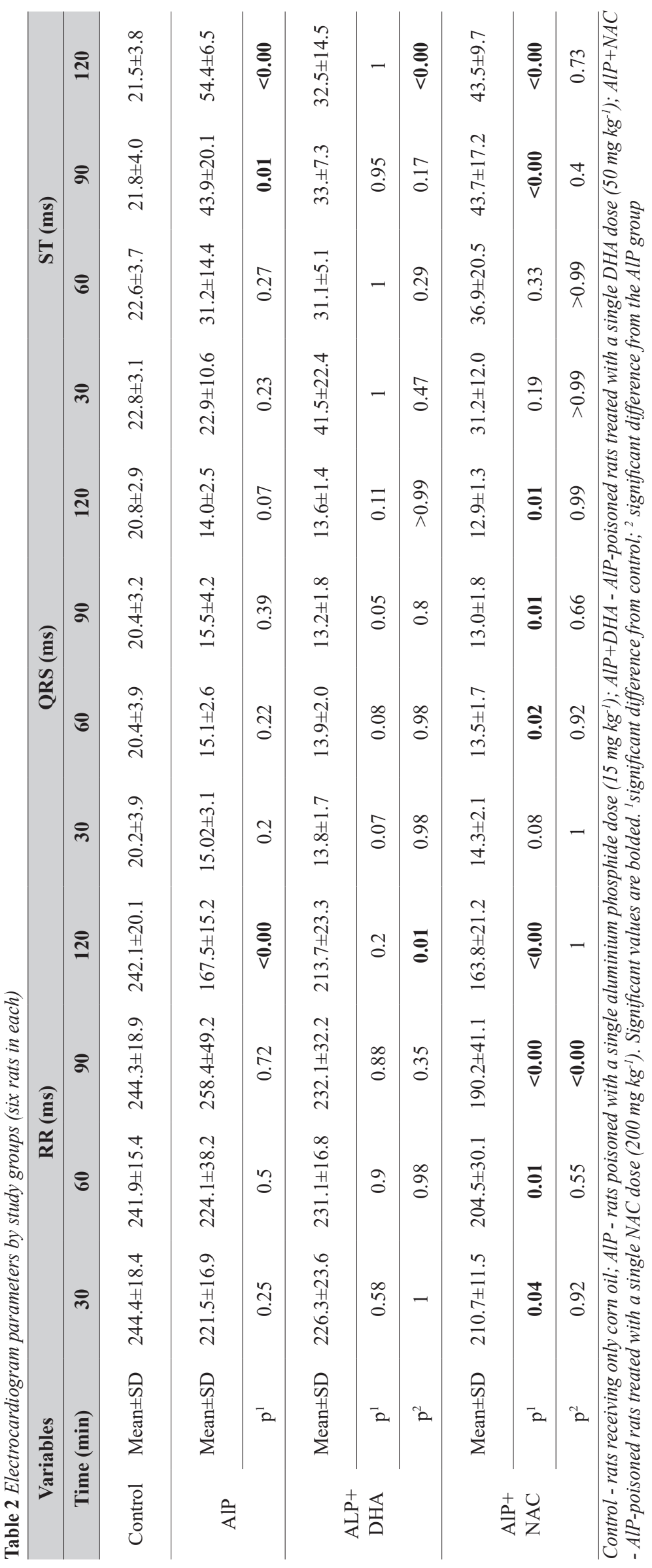


successfully reversed RR interval shortening to normal. The QRS complex and the QTc interval are indicative of electrical conductivity in the heart tissue $(37,38)$. Prolonged QTc interval is associated with ventricular tachyarrhythmias due to premature action potential in the late stages of depolarisation, which increases the risk of ventricular arrhythmias or fatal ventricular fibrillations and is associated with ECG findings called Torsades de pointes (39). In this study, AlP poisoning caused a significant increase in the QTc interval with a non-significant decrease in QRS complex interval $60 \mathrm{~min}$ after the poisoning. This increase in the QTc interval could be a sign of deadly arrhythmias in animals. Administration of DHA and NAC restored it to normal.

NAC administration, however, had no significant effect on blood pressure and survival time. In fact, instead of lowering SI, NAC increased it above all other groups. According to Akturi et al. (40) one plausible reason for high SI could be the anaphylactic shock associated with NAC. Anaphylactic shock seems to be a result of the activation of histamine receptors, stimulation of endothelial cells, and the release of nitric oxide (41).

NAC was also inferior to DHA in correcting the ST elevation. It led to a significant drop in the QRS complex and, ultimately, did not save the rats from death. Yet a number of poisoning treatment centres currently use NAC as an antioxidant in AlP poisoning management. Our findings warn against its use as it may exacerbate the symptoms and even accelerate death caused by AlP poisoning. Clearly, even though oxidative stress is involved in AlP toxicity, it certainly is not the main mechanism of its action.

Speaking of the mechanism of action, we still do not know through which mechanisms DHA normalised the ECG parameters and stabilised the haemodynamics in the poisoned rats. Some authors $(21,42)$ point to the recovery of blood volume, improved tissue oxygenation, and restored cell respiration through the activation of cytochrome $\mathrm{C}$ oxidase.

Whatever the mechanism(s), the most important goal in poisoning management is to prevent death, which has been ignored by many animal studies of AlP poisoning. Most of them were focused on alleviating symptoms instead of addressing this key issue $(5,10,11,27,43,44)$. Our study, in turn, has identified DHA as a promising treatment for patients poisoned with rice tablets.

\section{Conflict of interest}

None to declare.

\section{Funding}

This article supported by Kerman University of Medical Sciences (project no. 96000477).

\section{REFERENCES}

1. Hashemi-Domeneh B, Zamani N, Hassanian-Moghaddam H, Rahimi M, Shadnia S, Erfantalab P, Ostadi A. A review of aluminium phosphide poisoning and a flowchart to treat it. Arh Hig Rada Toksikol 2016;67:183-93. doi: 10.1515/aiht-2016-672784

2. Mohan B, Gupta V, Ralhan S, Gupta D, Puri S, Wander GS, Singh B. Role of extracorporeal membrane oxygenation in aluminum phosphide poisoning-Induced reversible myocardial dysfunction: A novel therapeutic modality. J Emerg Med 2015;49:651-6. doi: 10.1016/j.jemermed.2015.06.071

3. Karami-Mohajeri S, Jafari A, Abdollahi M. Comprehensive review of the mechanistic approach and related therapies to cardiovascular effects of aluminum phosphide. Int J Pharmacol 2013;9:493-500. doi: 10.3923/ijp.2013.493.500

4. Mehrpour O, Jafarzadeh M, Abdollahi M. A systematic review of aluminium phosphide poisoning. Arh Hig Rada Toksikol 2012;63:61-73. doi: 10.2478/10004-1254-63-2012-2182

5. Yan H, Xiang P, Zhang S, Shen B, Shen M. Diagnosis of aluminum phosphide poisoning using a new analytical approach: forensic application to a lethal intoxication. Int J Legal Med 2017;131:1001-7. doi: 10.1007/s00414-017-1562-1

6. Schoonbroodt D, Guffens P, Jousten P, Ingels J, Grodos J. Acute phosphine poisoning? A case report and review. Acta Clin Belg 1992;47:280-4. doi: 10.1080/17843286.1992.11718243

7. Bumbrah GS, Krishan K, Kanchan T, Sharma M, Sodhi GS. Phosphide poisoning: a review of literature. Forensic Sci Int 2012;214:1-6. doi: 10.1016/j.forsciint.2011.06.018

8. Bashardoust B, Farzaneh E, Habibzadeh A, Seyyed Sadeghi MS. Successful treatment of severe metabolic acidosis due to acute aluminum phosphide poisoning with peritoneal dialysis: a report of 2 cases. Iran J Kidney Dis 2017;11:165-7. PMID: 28270650

9. Saleki S, Ardalan FA, Javidan-Nejad A. Liver histopathology of fatal phosphine poisoning. Forensic Sci Int 2007;166:190-3. doi: 10.1016/j.forsciint.2006.05.033

10. Mendonca M, Tamas C, Kiraly L, Talo H, Rajah J. Successful use of ECLS in cardiopulmonary failure due to aluminum phosphide poising. Egypt J Crit Care Med 2016;4:33-5. doi: 10.1016/j.ejccm.2016.02.004

11. Mehrpour O, Amouzeshi A, Dadpour B, Oghabian Z, Zamani N, Amini S, Hoffman RS. Successful treatment of cardiogenic shock with an intraaortic balloon pump following aluminium phosphide poisoning. Arh Hig Rada Toksikol 2014;65:121-7. doi: 10.2478/10004-1254-65-2014-2393

12. Hassanian-Moghaddam H, Zamani N, Rahimi M, Hajesmaeili M, Taherkhani M, Sadeghi R. Successful treatment of aluminium phosphide poisoning by extracorporeal membrane oxygenation. Basic Clin Pharmacol Toxicol 2016;118:243-6. doi: 10.1111/ bcpt.12481

13. Marashi SM, Nasri Nasrabadi Z, Jafarzadeh M, Mohammadi S. Hydroxyethyl starch could save a patient with acute aluminum phosphide poisoning. Acta Med Iran 2016;54:475-8. PMID: 27424021

14. Jafari A, Baghaei A, Solgi R, Baeeri M, Chamanara M, Hassani S, Gholami M, Ostad SN, Sharifzadeh M, Abdollahi M. An electrocardiographic, molecular and biochemical approach to explore the cardioprotective effect of vasopressin and milrinone against phosphide toxicity in rats. Food Chem Toxicol 2015;80:182-92. doi: 10.1016/j.fct.2015.02.022 
15. Azad A, Lall SB, Mittra S. Effect of N-acetylcysteine and L-NAME on aluminium phosphide induced cardiovascular toxicity in rats. Acta Pharmacol Sin 2001;22:298-304. PMID: 11742581

16. Erni B, Siebold C, Christen S, Srinivas A, Oberholzer A, Baumann U. Small substrate, big surprise: fold, function and phylogeny of dihydroxyacetone kinases. Cell Mol Life Sci 2006;63:890-900. doi: 10.1007/s00018-005-5518-0

17. Hirabayashi J. On the origin of elementary hexoses. Q Rev Biol 1996;71:365-80. PMID: 8927690

18. Jeffery J, Jörnvall H. Enzyme relationships in a sorbitol pathway that bypasses glycolysis and pentose phosphates in glucosemetabolism. Proc Natl Acad Sci USA 1983;80:901-5. doi: 10.1073/pnas.80.4.901

19. Macauley S, McNeil B, Harvey LM. The genus Gluconobacter and its applications in biotechnology. Crit Rev Biotechnol 2001;21:1-25. doi: 10.1080/20013891081665

20. Faurschou A, Janjua NR, Wulf HC. Sun protection effect of dihydroxyacetone. Arch Dermatol 2004;140:886-7. doi: 10.1001/archderm.140.7.886

21. Laborit H, inventor; Centre D'etudes Exper et Cliniques de Physiobiologi Pharm et Eut, assignee. Treatment of hemorrhagic shock. United States patent US4049795A. 1977 Sept 20.

22. Niknahad H, O'Brien PJ. Antidotal effect of dihydroxyacetone against cyanide toxicity in vivo. Toxicol Appl Pharmacol 1996;138:186-91. doi: 10.1006/taap.1996.0112

23. Niknahad H, Ghelichkhani E. Antagonism of cyanide poisoning by dihydroxyacetone. Toxicol Lett 2002;132:95-100. doi: 10.1016/S0378-4274(02)00016-4

24. Rashedinia M, Jamshidzadeh A, Mehrabadi AR, Niknahad H. Prevention of phosphine-induced cytotoxicity by nutrients in HepG2 cells. Indian J Med Res 2016;144:560-5. doi: 10.4103/0971-5916.200896

25. Baeeri M, Shariatpanahi M, Baghaei A, Ghasemi-Niri SF, Mohammadi H, Mohammadirad A, Hassani S, Bayrami Z, Hosseini A, Rezayat SM, Abdollahi M. On the benefit of magnetic magnesium nanocarrier in cardiovascular toxicity of aluminum phosphide. Toxicol Ind Health 2013;29:126-35. doi: $10.1177 / 0748233711425074$

26. Anand R, Kumari P, Kaushal A, Bal A, Wani WY, Sunkaria A, Dua R, Singh S, Bhalla A, Gill KD. Effect of acute aluminum phosphide exposure on rats: a biochemical and histological correlation. Toxicol Lett 2012;215:62-9. doi: 10.1016/j. toxlet.2012.09.020

27. Tehrani H, Halvaie Z, Shadnia S, Soltaninejad K, Abdollahi M. Protective effects of $\mathrm{N}$-acetylcysteine on aluminum phosphideinduced oxidative stress in acute human poisoning. Clin Toxicol (Phila) 2013;51:23-8. doi: 10.3109/15563650.2012.743029

28. Joukar S, Zarisfi Z, Sepehri G, Bashiri A. Efficacy of Melissa officinalis in suppressing ventricular arrhythmias following ischemia-reperfusion of the heart: a comparison with amiodarone. Med Princ Pract 2014;23:340-5. doi: $10.1159 / 000363452$

29. Frohlich M, Driessen A, Bohmer A, Nienaber U, Igressa A, Probst C, Bouillon B, Maegele M, Mutschler M, and the TraumaRegister DGU. Is the shock index based classification of hypovolemic shock applicable in multiple injured patients with severe traumatic brain injury?-an analysis of the TraumaRegister DGU ${ }^{\circledR}$. Scand J Trauma Resusc Emerg Med 2016;24:148. doi: 10.1186/s13049-016-0340-2
30. Olaussen A, Blackburn T, Mitra B, Fitzgerald M. Review article: shock index for prediction of critical bleeding post-trauma: a systematic review. Emerg Med Australas 2014;26:223-8. doi: 10.1111/1742-6723.12232

31. Allgöwer M, Burri C. Shock-index. Ger Med Mon 1968;13:149. PMID: 5656857

32. Rady MY. The role of central venous oximetry, lactic acid concentration and shock index in the evaluation of clinical shock: a review. Resuscitation 1992;24:55-60. doi: 10.1016/03009572(92)90173-A

33. Rady MY, Smithline HA, Blake H, Nowak R, Rivers E. A comparison of the shock index and conventional vital signs to identify acute, critical illness in the emergency department. Ann Emerg Med 1994;24:685-90. doi: 10.1016/S01960644(94)70279-9

34. Merone M, Soda P, Sansone M, Sansone C. ECG databases for biometric systems: A systematic review. Expert Syst Appl 2017;67:189-202. doi: 10.1016/j.eswa.2016.09.030

35. Fox K, Borer JS, Camm AJ, Danchin N, Ferrari R, Lopez Sendon JL, Steg PG, Tardif JC, Tavazzi L, Tendera M, Heart Rate Working Group. Resting heart rate in cardiovascular disease. J Am Coll Cardiol 2007;50:823-30. doi: 10.1016/j. jacc.2007.04.079

36. Soltaninejad K, Beyranvand MR, Momenzadeh SA, Shadnia $\mathrm{S}$. Electrocardiographic findings and cardiac manifestations in acute aluminum phosphide poisoning. J Forensic Leg Med 2012;19:291-3. doi: 10.1016/j.jflm.2012.02.005

37. Baghaei A, Hajimohammadi N, Baeeri M, Mohammadirad A, Hassani S, Abdollahi M. On the protection of ALP cardiovascular toxicity by a Novel mixed herbal medicine; Role of oxidative stress and cellular ATP. Asian J Anim Vet Adv 2014;9:302-11. doi: 10.3923/ajava.2014.302.311

38. Chugh SN, Dushyant, Ram S, Arora B, Malhotra KC. Incidence \& outcome of aluminium phosphide poisoning in a hospital study. Indian J Med Res 1991;94:232-235. PMID: 1937606

39. Vandael E, Vandenberk B, Vandenberghe J, Willems R, Foulon V. Risk factors for QTc-prolongation: systematic review of the evidence. Int J Clin Pharm 2017;39:16-25. doi: 10.1007/s11096016-0414-2

40. Atkuri KR, Mantovani JJ, Herzenberg LA, Herzenberg LA. $\mathrm{N}$-Acetylcysteine - a safe antidote for cysteine/glutathione deficiency. Curr Opin Pharmacol 2007;7:355-9. doi: 10.1016/j. coph.2007.04.005

41. Kemp SF, Lockey RF. Anaphylaxis: a review of causes and mechanisms. J Allergy Clin Immunol 2002;110:341-8. doi: 10.1067/mai.2002.126811

42. Valmas N, Zuryn S, Ebert PR. Mitochondrial uncouplers act synergistically with the fumigant phosphine to disrupt mitochondrial membrane potential and cause cell death. Toxicology 2008;252:33-9. doi: 10.1016/j.tox.2008.07.060

43. Asghari MH, Abdollahi M, de Oliveira MR, Nabavi SM. A review of the protective role of melatonin during phosphineinduced cardiotoxicity: focus on mitochondrial dysfunction, oxidative stress and apoptosis. J Pharm Pharmacol 2017;69:23643. doi: 10.1111/jphp.12682

44. Trakulsrichai S, Kosanyawat N, Atiksawedparit P, Sriapha C, Tongpoo A, Udomsubpayakul U, Rittilert P, Wananukul W. Clinical characteristics of zinc phosphide poisoning in Thailand. Ther Clin Risk Manag 2017;13:335-40. doi: 10.2147/TCRM. S129610 


\section{Dihidroksiaceton kao definitivni lijek za trovanje aluminijevim fosfidom u štakora}

Aluminijev fosfid (AlP) je pesticid koji u dodiru s vodom, vlagom ili želučanom kiselinom oslobađa iznimno toksičan plin fosfin. Smrtnost u ljudi je od 70 do $100 \%$ zbog srčanog šoka i refraktorne hipotenzije. Dihidroksiaceton (DHA) jednostavan je ketonski ugljikovodik koji se mahom rabi kao preparat za tamnjenje kože. Osim toga, rabi se u liječenju niskog krvnog tlaka i srčanog šoka, a djeluje tako što volumen krvi i stanično disanje vraća na normalnu razinu. Cilj je ovoga istraživanja bio ispitati njegov utjecaj na hemodinamiku i elektrokardiogram (EKG) u mužjaka Wistar štakora otrovanih aluminijevim fosfidom. Životinje su podijeljene u sljedeće skupine: kontrolnu (koja je jednokratno primila $1 \mathrm{~mL}$ kukuruznog ulja na usta), AlP (koja je jednokratno primila $15 \mathrm{mg} \mathrm{kg}^{-1} \mathrm{AlP}-\mathrm{a}$ otopljenog u kukuruznom ulju na usta), AlP plus DHA (koja je jednokratno primila $50 \mathrm{mg} \mathrm{kg}^{-1}$ DHA 30 min nakon trovanja AlP-om) te AlP plus $N$-acetilcistein (NAC) (koja je jednokratno primila $200 \mathrm{mg} \mathrm{kg}^{-1} \mathrm{NAC}-\mathrm{a} 30 \mathrm{~min}$ nakon trovanja AlP-om). Životinje su potom anestezirane i u idućih 120 min mjereni su im EKG, sistolički krvni tlak i broj otkucaja srca. Primjena AlP-a samog ili u kombinaciji s NAC-om bila je povezana s progresivnom hipotenzijom, tahikardijom i poremećajima u EKG-u te je dovela do 100-postotne smrtnosti unutar tri sata od trovanja. S druge pak strane, DHA je osigurao 100-postotno preživljenje otrovanih štakora i spriječio poremećaje u EKG-u i hemodinamici izazvane trovanjem AlP-om. Još nije jasan osnovni mehanizam djelovanja DHA, ali naši rezultati upućuju na obećavajući terapeutski potencijal DHA u liječenju otrovanja AlP-om.

KLJUČNE RIJEČI: akutna toksičnost; AlP; DHA; pesticidi; refraktorna hipotenzija; N-acetilcistein 